\title{
Trade and legislation: consequences for the conservation of lichens in the Nepal Himalaya
}

\author{
Shiva Devkota ${ }^{1}$ (D) Ram Prasad Chaudhary ${ }^{2,3} \cdot$ \\ Silke Werth $^{1,4} \cdot$ Christoph Scheidegger ${ }^{1}$
}

Received: 10 November 2016/Revised: 27 April 2017/Accepted: 14 May 2017/

Published online: 24 May 2017

(C) Springer Science+Business Media Dordrecht 2017

\begin{abstract}
Lichen harvest and trade are closely associated with the livelihood of most of the rural people in Western Nepal. The present study investigates the commercial collection of lichens, quantifies the traded volume and relates it to a market scenario, and discusses conservation measures in relation to established legal practices in Nepal. Data on lichen trade and revenue generated for the 12 years (2000-2011) were collected and analyzed from 74 districts of Nepal. Voucher specimens were deposited at TUCH (Tribhuvan University Central Herbarium) in Nepal. The lichens collected in West Nepal are mainly used in international trade, while those in East Nepal are used locally for food. A total of 20 commercially important species of lichens were identified from five trade centers and one local market. During 2000-2011, Nepal legally exported 2020 tons of lichens and collected NRs 25,293,305 (USD 240,000). The average annual quantity of turnover was 168 tons, though it is estimated that much was exported illegally. The hill districts in Nepal, which traded 1774 tons, were more important for the collection of commercial lichen species than the Mountainous and inner-Tarai districts, which traded 167 and 108 tons, respectively. Through the Forest Act, Forest Regulations and its amendment in 2011, the collection of lichens for harvest, trade and export in any crude or processed form was banned. However, the legislation lacks an effective implementation strategy, and
\end{abstract}

Communicated by Pradeep Kumar Divakar.

This article belongs to the Topical Collection: Biodiversity exploitation and use.

Shiva Devkota

shiva.devkota@gmail.com

1 Swiss Federal Research Institute WSL, Zürcherstrasse 111, 8903 Birmensdorf, Switzerland

2 Central Department of Botany, Tribhuvan University, Kirtipur, Kathmandu, Nepal

3 Research Centre for Applied Science and Technology (RECAST), Tribhuvan University, Kirtipur, Nepal

4 Institute of Plant Sciences, University of Graz, Holteigasse 6, 8010 Graz, Austria 
sustainable harvest of lichen resources based on scientific data would better serve local livelihood and lichen conservation in Nepal.

Keywords Legislation · Revenue - Cross-border trade $\cdot$ Socioeconomics $\cdot$ Sustainable management

\section{Introduction}

For millennia, non-timber forest products (NTFPs) have provided significant contributions to traditional health care systems and local economies, have represented cultural values, and have been important sources of food (FAO 1995). More than 95\% of the harvested quantity of medicinal and aromatic plants (MAPs) from Nepal is traded to India, and the expected annual export value is USD 3.2-12.8 million (Edwards 1996; Olsen 2005). Among the NTFPs/MAPs, the value of lichens for income generation has been undervalued in Nepal (Maraseni and Shivakoti 2003; Humagain and Shrestha 2010).

Lichens have been utilized for industrial uses, mainly for brewing and distilling, for tanning and dying, as ingredients in cosmetics and perfumes, and as pharmaceutical agents (Llano 1944). The lichens collected in Nepal are sold in India and preferred to prepare aromatic fixatives and incense, and as dying agents (Maraseni and Shivakoti 2003). Different ethnic communities of Nepal use lichens for their medicinal value, food value, ritual and spiritual value, aesthetic and decorative value, bedding value, and ethno-veterinary value (Devkota et al. 2017). In India, apart from making end products, wholesalers supply lichens with different qualities to various cities in India, such as Kannauj, Mumbai, Delhi, Kolkata, Varanasi and Lucknow, as well as to other countries, like the United Kingdom and Saudi Arabia (Richardson 1992). It is very common to find lichens in local grocery shops in most cities of India (Upreti et al. 2005), but not in Nepal.

The Government of Nepal $(\mathrm{GoN})$ has introduced a series of legal provisions and has fixed a royalty rate to manage forest resources, which is included in Annex III of the Forest Regulations (1995) (GoN/MoFSC 1995). The Department of Forest collected about NRs 76.14 million (USD 0.72 million) as revenue from the sale of 21,154 tons of NTFPs/MAPs of different categories in the fiscal year 2013/2014 (GoN/MoFSC/DoF 2014). A revised list in the Forest Regulations enforced in 2015 included 214 plant species grouped into seven categories: roots and rhizomes (48), bark (25), leaves and stems (30), flowers and inflorescences (16), fruits and seeds (66), entire plants (21), and gum and resin (8). The government has included lichens under the "entire plant" category with a royalty rate of NRs $15 / \mathrm{kg}$. The government has also prioritized 30 MAPs/NTFPs, including lichens, for research and economic development (HNCC 2006). Unfortunately, legal practices for the conservation of lichen species are changed from time to time without proper scientific backing, similar to what happened with wild orchids (Subedi et al. 2013).

The main aims of this paper were to: (i) identify the lichen species traded within Nepal and in trans-border trade; (ii) review existing legislation, and (iii) recommend more feasible and sustainable practices for the trade, management and conservation of lichens. 


\section{Methods}

\section{Study area}

The present study was conducted in important trade centers located in district headquarters of the Dadeldhura $\left(29^{\circ} 18^{\prime} 13.39^{\prime \prime} \mathrm{N}, \quad 80^{\circ} 35^{\prime} 30.56^{\prime \prime} \mathrm{E}\right)$, Baitadi $\left(29^{\circ} 33^{\prime} 38.17^{\prime \prime} \mathrm{N}\right.$, $\left.80^{\circ} 25^{\prime} 08.30^{\prime \prime} \mathrm{E}\right)$, Jajarkot $\left(28^{\circ} 41^{\prime} 55.57^{\prime \prime} \mathrm{N}, 82^{\circ} 11^{\prime} 59.64^{\prime \prime} \mathrm{E}\right)$, Rolpa $\left(28^{\circ} 18^{\prime} 15.64^{\prime \prime} \mathrm{N}\right.$, $\left.82^{\circ} 38^{\prime} 17.79^{\prime \prime} \mathrm{E}\right)$, Banke $\left(28^{\circ} 04^{\prime} 18.59^{\prime \prime} \mathrm{N}, 81^{\circ} 37^{\prime} 24.92^{\prime \prime} \mathrm{E}\right)$, and Taplejung $\left(27^{\circ} 21^{\prime} 11.41^{\prime \prime} \mathrm{N}\right.$, $87^{\circ} 39^{\prime} 56.99^{\prime \prime} \mathrm{E}$ ) districts of Nepal. The Dadeldhura and Baitadi districts are located along the western border of Nepal and India, Rolpa and Jajarkot are midhill districts, Banke is situated on the southern border of Nepal, and Taplejung is a mountainous district on the eastern and northern border of Nepal. The major trade route to India from Nepal is from the southern border; Banke district, which is situated on the southern plain bordering India, was therefore selected for finding regional wholesalers' stores and for collecting information on Indo-Nepal trade practices. The local uses of lichens in the eastern part of Nepal were investigated previously by authors SD and RPC, and the Taplejung district in this region was therefore selected for documenting locally traded species (Fig. 1).

\section{Data collection}

For the study of traded species and Indo-Nepal trade, five main wholesale trade centers were visited between July 2010 and January 2011 in the western parts of Nepal. Taplejung, a mountainous district, was visited during 2011-2013 to document locally traded species. As trading of lichens without processing was illegal until 2011, good contact and understanding were established with wholesalers in order to visit their stores and collect samples

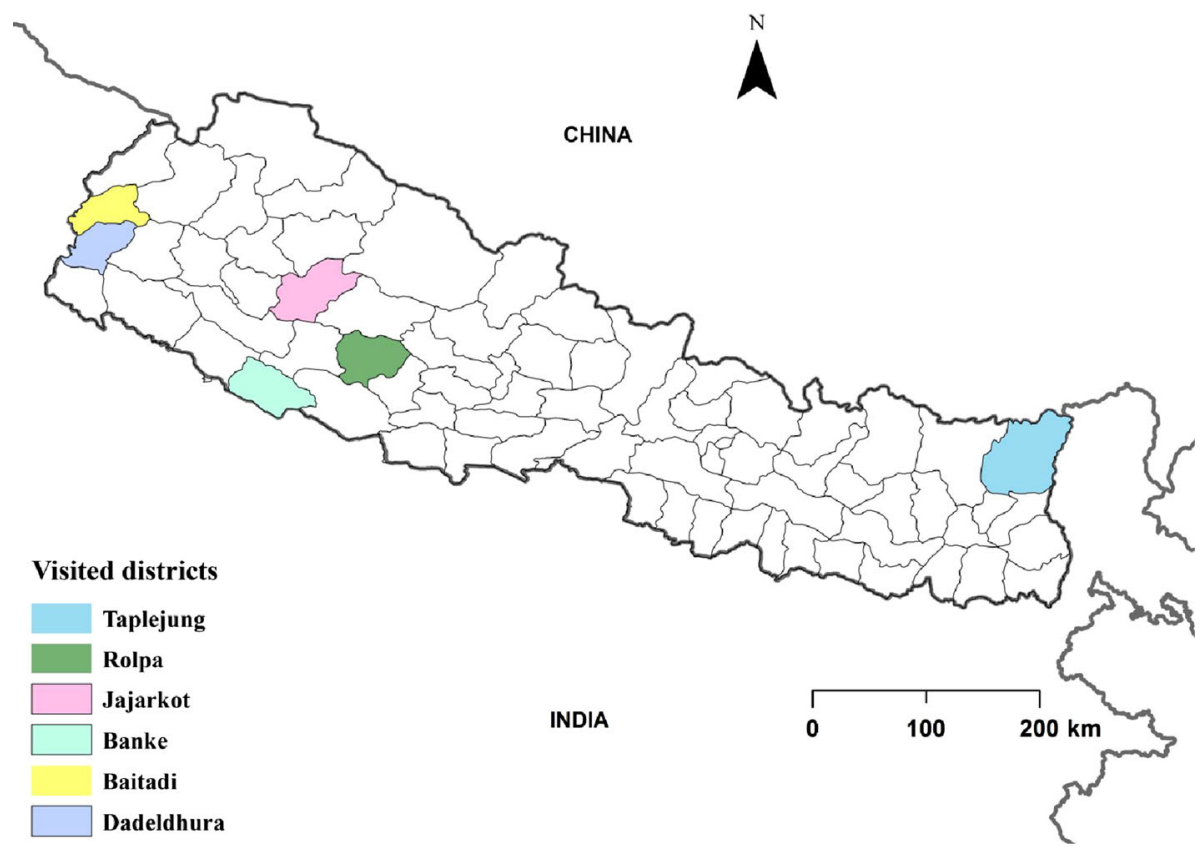

Fig. 1 Map of the study area showing the five districts in the western part and one district in eastern Nepal 
of traded species for identification, and to obtain data on trade volumes. About $200 \mathrm{~g}$ of mixed lichen material was procured from ten wholesalers (two traders from each district) in the Banke, Dadeldhura, Baitadi, Rolpa and Jajarkot districts. In Taplejung, specimens from the local market were collected to make herbarium vouchers. Lichen collection methods were documented by consulting local vendors in Taplejung. We applied semistructured questionnaires specifically designed to obtain information from the traders (Table 1). From the mixed collections, morphologically different species of lichen were segregated from each district to complete detailed taxonomic identifications.

\section{Lichen identification}

The lichens were identified by studying morphology, anatomy and chemistry. Relevant keys, monographs and documentation on Indian lichens were used (Awasthi 2007; Singh and Sinha 2010). The morphological characteristics of the lichen specimens were examined with a Leica EZ4 stereomicroscope and a LeicaTM DM 500 optical microscope. Lichen substances were identified with color spot tests using aqueous Potassium hydroxide $(\mathrm{KOH})$; $[\mathrm{K}]$, bleaching powder or aqueous solution of Calcium hypochlorite $\left(\mathrm{Ca}(\mathrm{ClO})_{2}\right) ;[\mathrm{C}]$ and aqueous solution of p-phenylenediamine $\left(\mathrm{C}_{6} \mathrm{H}_{4}\left(\mathrm{NH}_{2}\right)_{2}\right)$; [Pd]. Not all dried lichen samples could be identified in Nepal. Unidentified specimens were later identified at the Swiss Federal Research Institute WSL, Switzerland, with standard thin-layer chromatography (TLC) techniques (Culberson and Kristinsson 1970; Culberson 1972). Specimens are deposited in the Tribhuvan University Central Herbarium (TUCH), Kirtipur, Kathmandu, Nepal.

\section{Traded volume and revenue collection}

To quantify the legally traded volume of lichens and the revenue generated, data from 74 district forest offices (DFOs) from the last 12 fiscal years (2000-2011) were compiled and analyzed from Hamro Ban (Our Forests), a yearly official publication of the Department of Forests, Ministry of Forest and Soil Conservation, Government of Nepal. Of the 75 districts in Nepal, no data were available from Mustang district, which is located in the transHimalayan Arid Zone and characterized by high altitude and a semi-desert environment (NTNC 2014); thus, no lichen trade was expected to occur in this area.

Lichen prices in the main trade centers of Nepal and India were obtained from monthly newsletters published by the international research organization Asia Network for Sustainable Agriculture and Bio-resources (ANSAB, Kathmandu, Nepal). Prices from six consecutive years (2010-2015) were analyzed. Price statistics for Nepalganj and

Table 1 Questionnaire used for the traders

\begin{tabular}{ll}
\hline 1 & How many species of lichens are you buying and reselling? \\
3 & From where and whom do you buy them? \\
4 & What is the buying price/kg in last five years? \\
5 & What is the selling price/kg in last five years? \\
6 & Where do you sell these species? \\
7 & Based on which criteria do you assess the quality of the lichen material? \\
9 & What is the number of lichens traders from your city? \\
\hline
\end{tabular}


Kathmandu markets were available until lichen collection was completely banned since February 2011. Moreover, price lists from four trade centers in India, located in Delhi, Tanakpur, Lucknow and Kolkata, were reviewed and analyzed.

\section{Results}

\section{Collection methods employed by the local population}

Collection seasons differed according to the purpose of the collection. In the western districts, lichens were mainly collected for trade during the pre-monsoon months, i.e. December-April. In the eastern part of Nepal, lichen collection started after the end of the monsoon period, and the collection period was August to November so that the lichens could be used during festivals. Orders for lichen material were made by Indian traders from Tanakpur, Lucknow, Delhi, Kolkata and Kanpur with Nepalese traders residing near the India-Nepal border. Commercial collection of lichens in the western parts of Nepal has only been conducted during the last 15-20 years.

Normally, collectors walk $1-4 \mathrm{~km}$ to reach forests and spend 6-8 h in collection. Usually, at least two people, often belonging to the same family or friends or neighbors, visit the forest together. Children and adults, both male and female, are equally involved. Interestingly, the collection could be intentional or spontaneous while passing through the forests. Lichens are typically hand-picked by the collectors, but sometimes sticks, umbrellas or Nepalese knives (Khukurii) are used to strip lichens from the surface of their substrate. Lichens are collected in a jute sack or plastic bag. When collectors are back at home, they sort the lichens to remove contaminants such as mosses, bird feathers, unwanted lichens, leaves, and other plant parts.

\section{Commercially traded species}

Traded species were identified into 20 species under 14 genera (Table 2). The nomenclature of the identified species follows the MycoBank Database (2017; http://www. mycobank.org/). Of all the districts, the maximum number of species was identified from the wholesale stores in Banke $(n=17)$ and the minimum number was identified from the local weekly market in Taplejung $(\mathrm{n}=3)$. Hypotrachyna cirrhata $[=$ Everniastrum cirrhatum], H. nepalensis [=E. nepalense] and Parmotrema cetratum are high priority species and were traded from all six districts.

\section{Lichen market value, traded volume and contribution to the national revenue}

The trade in Taplejung was only at the local level, and lichens were sold in weekly markets on Tuesdays and Saturdays at the district headquarters. Seven vendors were involved in selling lichens, together with fresh vegetables and fruits, in a moderate quantity. Out of seven vendors (male 4, female 3), five were from the Limbu ethnic group and the remaining were from the Dalit and Brahman groups. These traders often sell lichens during festivals like Dashain and Tihar. The average selling price for lichens was NRs 210 per $\mathrm{kg}$ (1 USD = NRs 106), but the price depended on the availability of material and season. On average, each vendor sold $27 \mathrm{~kg}$ annually, yielding a total of around $189 \mathrm{~kg}$ for the seven vendors. The vendors obtained lichens from collectors, and sometimes they were also 
Table 2 List of traded lichens species from six different districts of Nepal

\begin{tabular}{|c|c|c|c|c|c|c|c|c|c|}
\hline \multirow[t]{2}{*}{ SN } & \multirow[t]{2}{*}{ Species } & \multirow[t]{2}{*}{ Family } & \multirow[t]{2}{*}{ Voucher } & \multicolumn{6}{|c|}{ Districts } \\
\hline & & & & 1 & 2 & 3 & 4 & 5 & 6 \\
\hline 1 & Dendriscosticta platyphylla & Lobariaceae & SD11 & + & + & + & + & + & - \\
\hline 2 & Dolichousnea longissima & Parmeliaceae & SD13 & + & + & + & + & - & - \\
\hline 3 & Heterodermia diademata & Physciaceae & SD08 & + & + & + & + & + & - \\
\hline 4 & H. leucomelos & Physciaceae & SD07 & + & + & + & + & + & - \\
\hline 5 & Hypotrachyna sp. & Parmeliaceae & SD17a & - & - & + & - & - & - \\
\hline 6 & H. cirrhata & Parmeliaceae & SD05 & + & + & + & + & + & + \\
\hline 7 & H. nepalensis & Parmeliaceae & SD06 & + & + & + & + & + & + \\
\hline 8 & Leptogium sp. & Collemataceae & SD12 & + & + & + & + & + & - \\
\hline 9 & L. burnetiae & Collemataceae & SD19 & - & - & + & - & - & - \\
\hline 10 & Lobaria retigera & Lobariaceae & SD03 & + & + & + & + & + & - \\
\hline 11 & Parmelia sp. & Parmeliaceae & SD10 & + & + & + & + & + & - \\
\hline 12 & Parmotrema cetratum & Parmeliaceae & SD02 & + & + & + & + & + & + \\
\hline 13 & Peltigera sp. & Peltigeraceae & SD20c & - & - & - & - & + & - \\
\hline 14 & P. polydactylon & Peltigeraceae & SD14a & - & + & - & - & - & - \\
\hline 15 & Phaeophyscia hispidula & Physciaceae & SD01 & + & + & + & + & + & - \\
\hline 16 & Ramalina sp. & Ramalinaceae & SD09d & + & - & + & - & - & - \\
\hline 17 & $R$. sinensis & Ramalinaceae & SD15 & - & + & + & + & - & - \\
\hline 18 & Stereocaulon sp. & Stereocaulaceae & SD16 & - & + & - & - & - & - \\
\hline 19 & Thamnolia vermicularis & Icmadophilaceae & SD04 & + & + & + & + & + & - \\
\hline \multirow[t]{2}{*}{20} & Usnea himalayana & Parmeliaceae & SD18 & - & - & + & - & - & - \\
\hline & & & Total & 13 & 15 & 17 & 13 & 12 & 3 \\
\hline
\end{tabular}

$1=$ Dadeldhura; $2=$ Baitadi; $3=$ Banke; $4=$ Jajarkot; $5=$ Rolpa; $6=$ Taplejung

involved in the collection. At the District Forest Office of Taplejung, there was no record of lichen collection or trade data.

The trade of lichens in the western parts of Nepal was much more important and was observed year round. Due to export restrictions on lichens in crude form and lack of extraction practices, until 2011, the trade of lichens was mostly secret and informal. Collectors from mountainous districts collected lichens and sold them to local traders or road head traders. Local traders supplied lichens in sacks containing 35-40 kg lichen either to district traders or directly to the wholesale traders in the Nepalganj and lowland districts. The average price of lichens in Dadeldhura, Baitadi, Rolpa and Jajarkot was NRs 85 and NRs 95 in the years 2010 and 2011, respectively. Evaluation of lichens for quality was not common. In rare cases, before lichens reached the main traders in the lowland from the midhill and mountainous districts, they were sorted and classified by local traders into "First grade" and "Second grade". The first or best grade consisted of a mixture of Hypotrachyna cirrhata, H. nepalensis and Parmotrema cetratum, whereas second grade consisted of about $50 \%$ species from first grade and a mixture of other species from Table 2 . The price of first grade lichens is typically NRs $10-15$ per kg more expensive than second grade lichens.

We compared prices from five important centers of lichen trade (Fig. 2). Data (2011-2015) for the four Indian cities (Tanakpur, Lucknow, Delhi and Kolkata) were 
compiled for their yearly average value from a series of ANSAB publications, as discussed in the methodology.

Out of the 75 districts in Nepal, revenue was only collected from 35 districts in the last 12 fiscal years (2000-2011), when permission for the collection and release letters for transport were granted (Fig. 3; Table 3). In the fiscal year 2000-2001, only $10 \mathrm{~kg}$ of lichens were collected, from Pyuthan, a hill district in the mid-western development region. The largest amount (578 tons) was traded from Baitadi during seven fiscal years. Baitadi is a hill district situated in the far-western region of Nepal. Hill districts yield larger amounts of lichen (total trade amount 1774.37 tons) than mountainous (167.35 tons) or inner-Tarai districts (108.49 tons). The total traded volume from the far-western region (986.68 tons) was higher than that from the mid-western (705.84 tons), central (269.23 tons), western (30.98 tons) or eastern region (27.47 tons).

District Forest Offices are authorized to collect royalties from lichen collecting, as specified in the Forest Regulations (1995). Table 4 shows statistics for the last twelve consecutive fiscal years of lichen collection. The total traded volume during the last twelve years was 2020 tons, and the revenue generated was USD 0.24 million. These data illustrate that the traded volume was not consistent across the years. The highest volume was traded in the fiscal year 2009-2010, when 567.08 tons were traded, and the lowest was during the fiscal year 2010-2011, when only 3.90 tons were sold.

\section{Discussion}

\section{Lichens, trade and legislation}

Even though the commercialization of lichen species in Nepal is a new trend in comparison with neighboring countries like India and China, we identified 20 species from 14 genera from six trade centers across the Nepal, from east to west, including mountainous

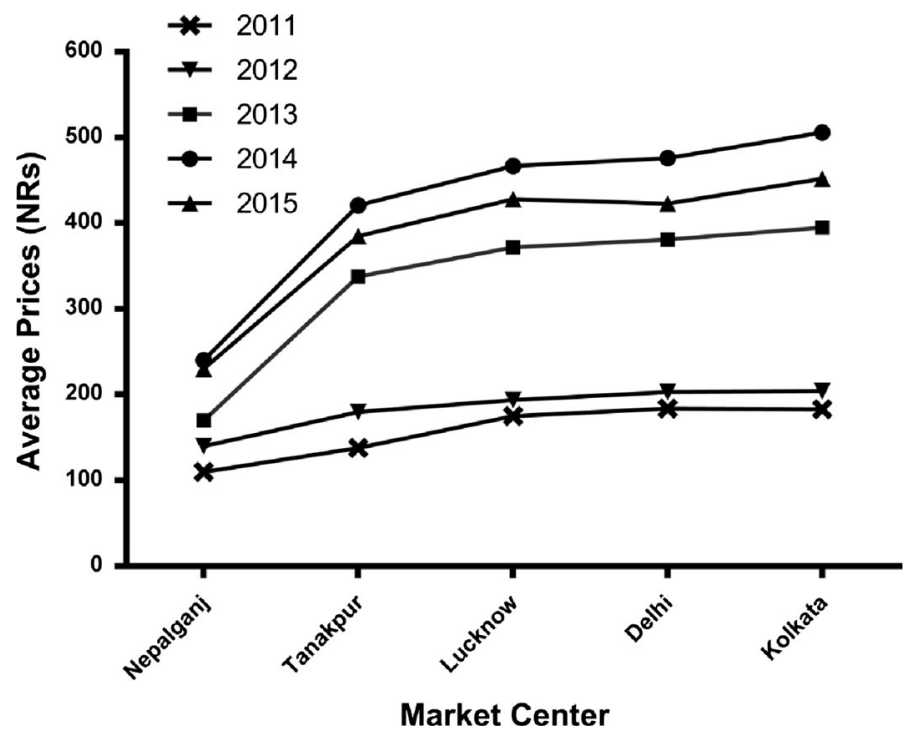

Fig. 2 Average prices of lichens in five market centers in India and Nepal during 2011-2015 (NRs per kg) 


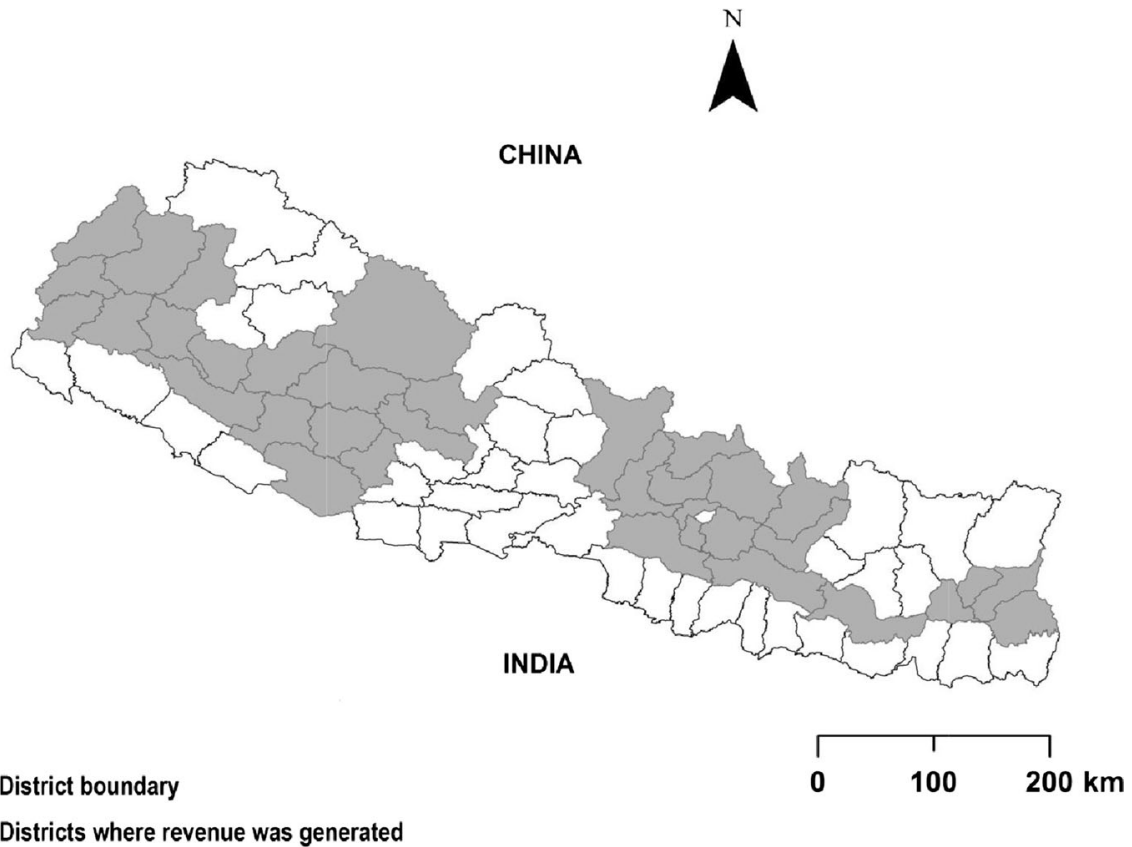

Fig. 3 Map of Nepal showing 35 districts where revenue was generated during the fiscal years 2000-2011 after permission letters were issued for the collection of lichens and release letters were issued for their transport

(Taplejung) and lowland districts (Banke). Upreti et al. (2005) reported 38 commercial species of lichens from seven states in India. We compared our findings with Indian commercial species, and found that nine species namely Dolichousnea longissima, Hypotrachyna cirrhata, H. nepalensis, Heterodermia diademata, H. leucomela, Lobaria retigera, Peltigera polydactylon, Ramalina sinensis and Thamnolia vermicularis were common and traded in both countries. Our research shows that, during 2000-2011, Nepal legally exported 2020.20 tons of lichens, with an annual average of 168.36 tons. The largest export was made during 2011, amounting to 567.08 tons (Fig. 4). The government lifted the ban on lichen collection for one month during that year (10 January-9 February 2011). Thus, all the stored lichens were exported to India within a single month.

In our study area, the main collection season differs according to the intentions and availabilities of the collectors. Also in India, the collection season varies among the regions. In Kumaun, India, the collection season is from October to April (Shah 2014), whereas in Garhwal, India, it is from April to May (Kumar 2009), similar to the collection season in the western parts of Nepal.

After establishing good courtesy with the traders, we visited their warehouses and counted the numbers of stacked sacks (Fig. 5a, b). Each sack contained 35-40 kg lichen. Trucks loaded with lichens run from north to south, with each truck carrying about 50 sacks (two tons of lichen). Commercial grading of lichens is not common in Nepal, but this practice is established in India. Three types of grading systems were described by Pant (2014) from Kumaun Himalaya, where Grade A is the best and contains no moss or bark; Grade B contains Grade A lichens mixed with mosses, twigs and bark; and Grade C mainly 


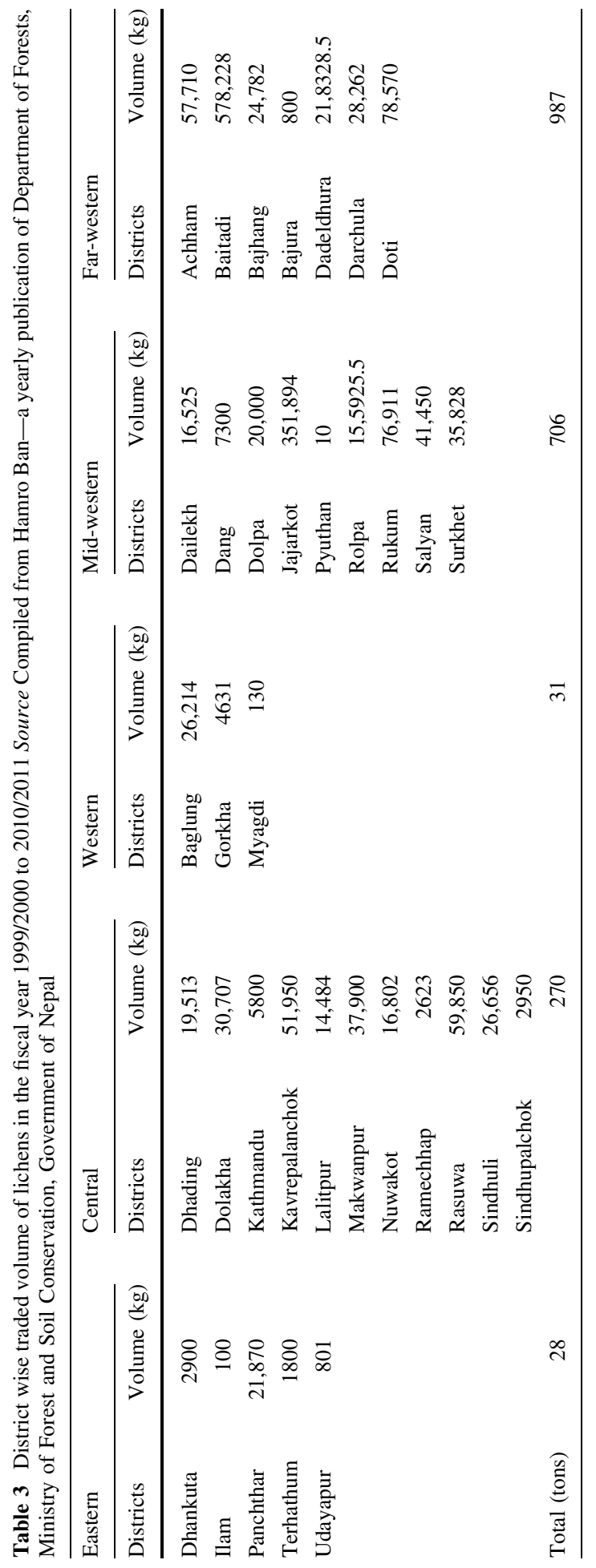


Table 4 Traded quantity and revenue collection of lichens from fiscal year 1999/2000 to 2010/2011 Source Compiled from Hamro Ban - a yearly publication of Department of Forests, Ministry of Forest and Soil Conservation, Government of Nepal

\begin{tabular}{llrlrr}
\hline $\begin{array}{l}\text { Fiscal year } \\
\text { (BS) }\end{array}$ & $\begin{array}{l}\text { Fiscal year } \\
\text { (AD) }\end{array}$ & $\begin{array}{l}\text { Quantity } \\
(\mathrm{kg})\end{array}$ & $\begin{array}{l}\text { Royalty rate (NRs/ } \\
\mathrm{kg})\end{array}$ & $\begin{array}{l}\text { Revenue } \\
\text { (NRs) }\end{array}$ & $\begin{array}{l}\text { Revenue } \\
\text { (USD) }\end{array}$ \\
\hline $2056 / 2057$ & $1999-2000$ & $323,283.00$ & 10 & $3,232,830.00$ & $30,498.40$ \\
$2057 / 2058$ & $2000-2001$ & $120,587.45$ & 10 & $1,205,874.50$ & $11,376.17$ \\
$2058 / 2059$ & $2001-2002$ & $161,504.00$ & 10 & $1,615,040.00$ & $15,236.23$ \\
$2059 / 2060$ & $2002-2003$ & $181,387.00$ & 10 & $1,813,870.00$ & $17,111.98$ \\
$2060 / 2061$ & $2003-2004$ & $167,160.00$ & 10 & $1,671,600.00$ & $15,769.81$ \\
$2061 / 2062$ & $2004-2005$ & $48,031.00$ & 10 & $480,310.00$ & 4531.23 \\
$2062 / 2063$ & $2005-2006$ & $26,530.00$ & 15 & $397,950.00$ & 3754.25 \\
$2063 / 2064$ & $2006-2007$ & $166,501.00$ & 15 & $2,497,515.00$ & $23,561.46$ \\
$2064 / 2065$ & $2007-2008$ & $184,669.00$ & 15 & $2,770,035.00$ & $26,132.41$ \\
$2065 / 2066$ & $2008-2009$ & $69,577.00$ & 15 & $1,043,655.00$ & 9845.80 \\
$2066 / 2067$ & $2009-2010$ & $567,075.00$ & 15 & $8,506,125.00$ & $80,246.46$ \\
$2067 / 2068$ & $2010-2011$ & 3900.00 & 15 & $58,500.00$ & 551.89 \\
& Total & $2,020,204.45$ & & $25,293,304.50$ & $238,616.08$ \\
\hline
\end{tabular}

BS Bikram Samvat (The Hindu calendar and official calendar of Nepal), AD Anno Domini (The Julian and Gregorian calendar), NRs Nepalese rupee, USD Unites States Dollar

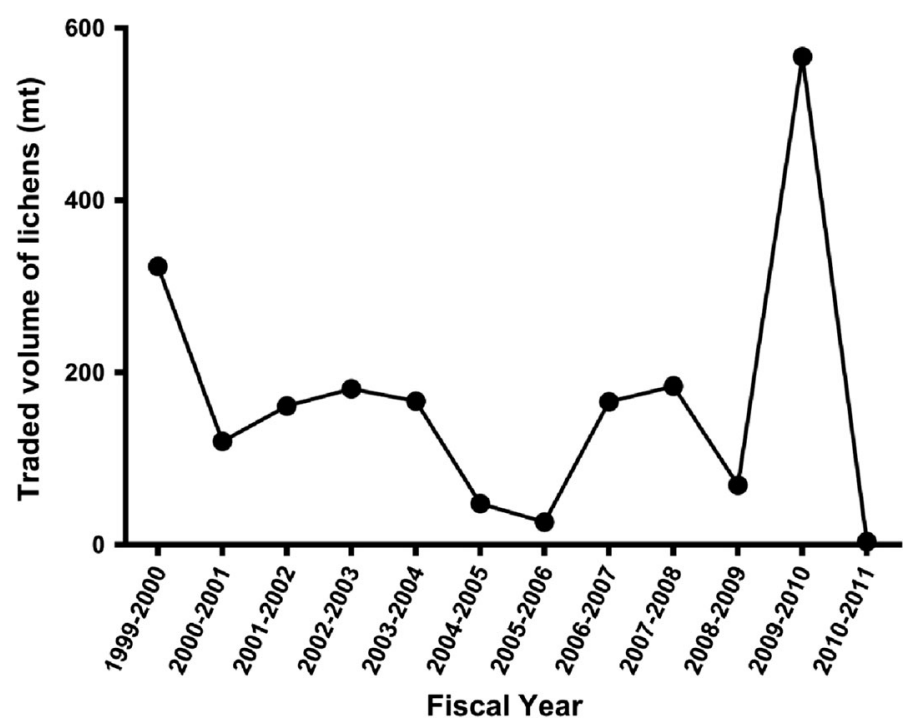

Fig. 4 Traded volume of lichens in different fiscal years. The largest volume was traded during 2009-2010 and the smallest was traded during 2005-2006 before collection and trade were completely banned

consists of saxicolous lichens commonly called "Patthar Chura". Similarly, four grades were reported by Shah (2014) from Uttarakhand: I, II, III and IV, defined by different species composition. 

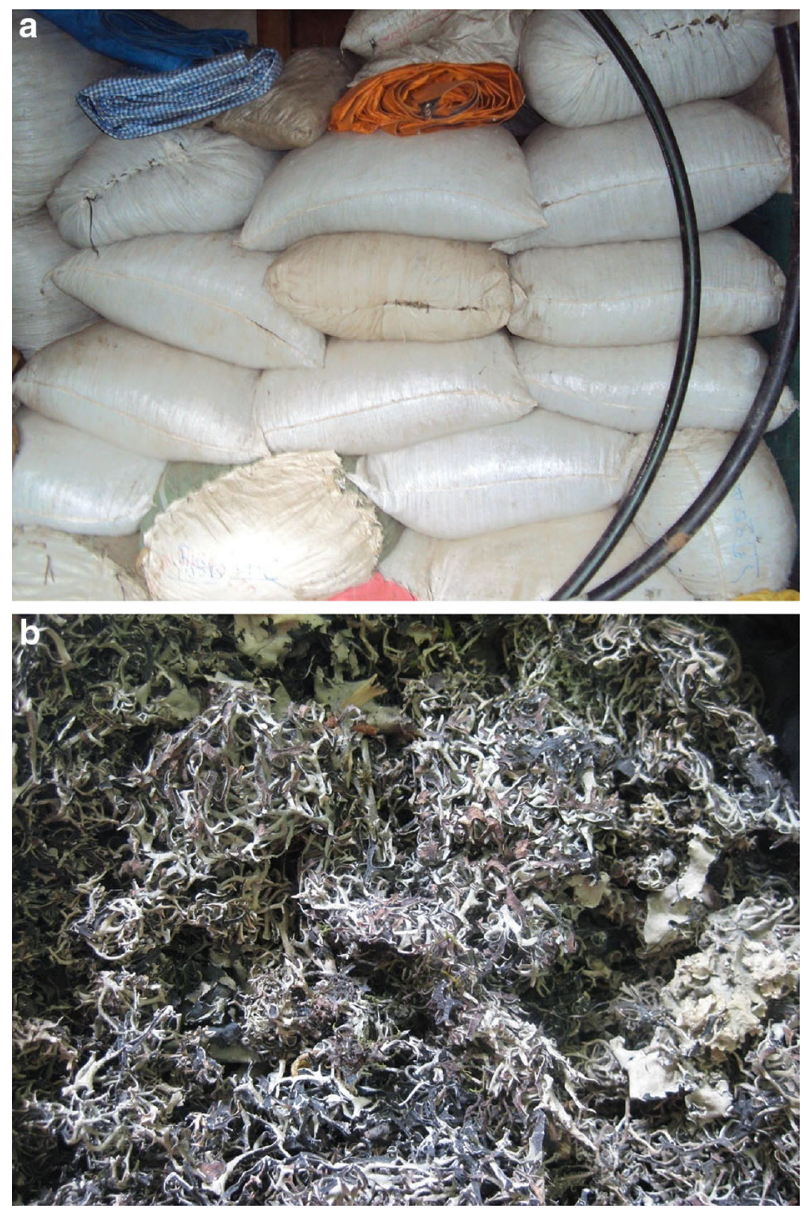

Fig. 5 a Sacks of lichens bought and stored in a wholesaler's hidden warehouse in Nepalganj, Banke district, Nepal. b Mixed lichens (as in Table 2) ready for export to India

\section{Legislation and implications for conservation}

The Government of Nepal imposed many provisions for the regulation (ban and restrictions) of lichen trade from 1995 to 2015 (Table 5). Forest Regulations (1995) banned lichens for trade unless a royalty of NRs 10 per $\mathrm{kg}$ was paid to the relevant District Forest Office, whereas Nepal Gazette 1996 completely banned lichen export in crude form. Nepal Gazette 2005 revised the royalty rate to NRs 15 per kg. Since 09 February 2011, the collection of lichens for commercial purposes and lichen trade has been completely banned.

Despite the present ban on lichen collection, lichens are collected and traded illegally, with no documentation of population sizes, carrying capacity of forests or species identities, and no application of scientific tools or management. Competition among poor collectors to collect more and more lichen also forces them to cut branches and spend days and nights in the forest to collect lichens (Maraseni and Shivakoti 2003). This trend definitely leads to the decline of lichens in the wild due to overexploitation. After a hard 
Table 5 Legal provisions and conservation measures imposed by the Government of Nepal for the conservation and management of lichens in chronological order

\begin{tabular}{|c|c|c|}
\hline Legal practices/notice & Enforced date & Remarks \\
\hline Forest Regulations, 1995 & $\begin{array}{l}2051.12 .20 \\
\quad(04.03 .1995)\end{array}$ & $\begin{array}{l}\text { (i) Collection permit or license have to be obtained from } \\
\text { District Forest Office (DFO)/Ministry of Forest and Soil } \\
\text { Conservation (MoFSC) for the collection of lichens by } \\
\text { mentioning the areas, quantity and the purpose of collection } \\
\text { (ii) Release order will be issued by DFO after proper tally of } \\
\text { collection according to the license issued for their } \\
\text { collection, check total collected quantities and collect fees/ } \\
\text { royalty } \\
\text { (iii) Royalty rate is NRs } 10 / \mathrm{kg}\end{array}$ \\
\hline Nepal Gazette, 1996 & $\begin{array}{l}2053.08 .10 \\
\quad(11.25 .1996)\end{array}$ & $\begin{array}{l}\text { (i) Banned to export in crude forms } \\
\text { (ii) Permission letter have to be obtained from Department of } \\
\text { Plant Resources (DPR) for the export in processed forms }\end{array}$ \\
\hline $\begin{array}{l}\text { Environmental Protection } \\
\text { Regulations, } 1997\end{array}$ & $\begin{array}{l}2054.3 .12 \\
\quad(06.26 .1997)\end{array}$ & $\begin{array}{l}\text { (i) Requirement of IEE (Initial Environmental Examination) } \\
\text { for the Medicinal and Aromatic Plants (MAPs) including } \\
\text { lichens, collected from a District for a duration of one year } \\
\text { of the amount not exceeding 5-50 tons. } \\
\text { (ii) Harvest level above } 50 \text { tons requires Environmental } \\
\text { Impact Assessment (EIA). }\end{array}$ \\
\hline Nepal Gazette, 2001 & $\begin{array}{l}2058.09 .16 \\
\quad(12.28 .2001)\end{array}$ & $\begin{array}{l}\text { (i) Certification letter is needed from Department of Plant } \\
\text { Resources (DPR) or Herbs Production and Processing } \\
\text { Company Limited (HPPCL) } \\
\text { (ii) Approval letter have to be obtained from Department of } \\
\text { Forests for the export of processed lichens }\end{array}$ \\
\hline Nepal Gazette, 2005 & $\begin{array}{l}2062.06 .10 \\
\quad(11.25 .2005)\end{array}$ & Revised royalty rate is NRs $15 / \mathrm{kg}$ \\
\hline DPR/MoFSC, 2006 & $\begin{array}{l}2063.03 \\
(06.2006)\end{array}$ & $\begin{array}{l}\text { Prioritized thirty Non-Timber Forest Products (NTFPs) } \\
\text { species, including lichens for research and economic } \\
\text { development }\end{array}$ \\
\hline Nepal Gazette, 2011 & $\begin{array}{l}2067.09 .26 \\
\quad(01.10 .2011)\end{array}$ & $\begin{array}{l}\text { (i) Lifted the ban on trade of lichens only for one month from } \\
\text { the date of issuance of this notice } \\
\text { (ii) Lichens must be collected and stored before this notice is } \\
\text { published } \\
\text { (iii) Completely banned for the collection, use, trade, and } \\
\text { export after one month of issuance of this notice }\end{array}$ \\
\hline DPR Newsletter, 2013 & $\begin{array}{l}2069.10 .15 \\
\quad(01.28 .2013)\end{array}$ & Draft of lichen collection directives to be submitted to MoFSC \\
\hline Nepal Gazette, 2015 & $\begin{array}{l}2072.07 .17 \\
\quad(03.11 .2015)\end{array}$ & $\begin{array}{l}\text { Royalty rate is again continuing as NRs } 15 / \mathrm{kg} \text { though banned } \\
\text { is not lifted }\end{array}$ \\
\hline
\end{tabular}

day of collecting, collectors cannot deal directly to the main traders and mainly have to depend on middlemen. Ineffective price-regulating practices cause the exploitation of large volumes of lichens for small amounts of money. Though legally regulated for the last few years, biological resources have been heavily extracted and exploited for trade (Olsen and Larsen 2003). Property rights of collectors and equitable benefit sharing must be ensured for the sustainable management of lichens and other NTFPs (Maraseni et al. 2006). Collection and trade of lichens in Uttarakhand, India has been more regulated since October 2004: the Forest Department and Uttarakhand Forest Development Corporation (UKVVN) provide training to registered collectors on sustainable harvesting practices and also play a 
crucial role in marketing and in creating a healthy relationship between collectors and buyers (Shah 2014). In Nepal, similar practices could be adopted rather than a complete ban on commercial lichen collection. Banning the use of resources without scientific investigation does not guarantee their protection over the long term (Olsen 1998; Olsen and Larsen 2003).

Primeval forests are more species rich in lichens than secondary forests (Rose 1992; Bergamini et al. 2005). Partial harvest of the green foliose lichen Lobaria pulmonaria for scientific or pharmaceutical purposes can be done without jeopardizing the survival of the lichen (Scheidegger and Werth 2009). However, overexploitation of lichens in the Himalaya for household and commercial uses is a major threat (Upreti et al. 2005). Overexploitation will cause a decrease in the local population density. Therefore, steps for lichen conservation should start with the maintenance of forest habitat, forest area and functional connectivity, together with sustainable management (Scheidegger and Werth 2009). Lichen diversity should be protected from destruction caused by anthropogenic activities (Molleman et al. 2011; Søchting 2015; Zedda and Rambold 2015), as habitat loss and fragmentation of natural forest landscapes cause tremendous declines in forestdwelling lichen populations (Scheidegger and Goward 2002).

\section{Conclusion}

The present study revealed 20 lichen species collected and traded in Nepal. Lichens represent a substantial contribution to the national revenue and also to the economic development of rural communities of Nepal. Little is known about the biodiversity of lichens in Nepal. We encourage other lichenologists to carry out further research on patterns of abundance, stock estimation and collection impact of the economically important lichen species of Nepal. We also urge authorities to develop lichen conservation strategies and revise haphazard legal decisions. Moreover, the sustainable harvest of lichen resources, rather than a total ban on lichen collection and trade should be considered. Further, promoting sustainable use of this biological resource could be supported because lichen species with the highest commercial values are locally abundant, also in secondary forests, and do not seem to be threatened by this use as long as their habitat is not irreversibly changed. Setting standards on how to harvest lichens in a sustainable way could be a better option to generate a moderate income for people who traditionally use this uncommon biological resource.

Acknowledgements We are grateful to the Department of National Parks and Wildlife Conservation (DNPWC), Ministry of Forest and Soil Conservation, Government of Nepal for the permission to conduct research and to traders in the studied areas for their cooperation. We thank Christine Keller from WSL, Switzerland for helping with TLC analyses. Prof. Krishna Kumar Shrestha CDB, TU, Sanjeev Kumar Rai DPR and Arjun Chapagain FECOFUN are acknowledged for their constructive discussion of legal aspects. We are also grateful to Jyoti Prasad Gajurel, Hem Bahadur Katuwal, Khem Lal Kadel and Rabindra Parajuli for their support during the field collections. We would like to thank Melissa Dawes for English editing and two anonymous reviewers for their helpful comments and suggestions on an earlier version of this manuscript. The project grant funded by the Swiss National Science Foundation (Grant JRP IZ70Z0_131338/1 to CS) is gratefully acknowledged. 


\section{References}

Awasthi DD (2007) A compendium of the macrolichens from India, Nepal and Sri Lanka. Bishen Singh Mahendra Pal Singh, DehraDun

Bergamini A, Scheidegger C, Stofer S et al (2005) Performance of macrolichens and lichen genera as indicators of lichen species richness and composition. Conserv Biol 19(4):1051-1062. doi:10.1111/j. 1523-1739.2005.00086.x

Culberson CF (1972) Improved conditions for the identification of lichen products by a standardized thinlayer chromotagraphic method. J Chromatogr 72:113-125. doi:10.1016/0021-9673(72)80013-X

Culberson CF, Kristinsson H (1970) A standardized method for the identification of lichen products. J Chromatogr 46:85-93. doi:10.1016/S0021-9673(00)83967-9

Devkota S, Chaudhary RP, Werth S, Scheidegger C (2017) Indigenous knowledge and use of lichens by the lichenophilic communities of the Nepal Himalaya. J Ethnobiol Ethnomed 13:1-10. doi:10.1186/ s13002-017-0142-2

Edwards DM (1996) Non-timber forest products from Nepal: aspects of the trade in medicinal and aromatic plants. Forest Research and Survey Center, Ministry of Forest and Soil Conservation, Babar Mahal, Kathmandu

FAO (1995) Non-wood forest products for rural income and sustainable forestry. Food and Agriculture Organization of the United Nations, Rome

GoN/MoFSC (1995) Forest Act, 1993 and Forest Regulation, 1995. Ministry of Forest and Soil Conservation, Government of Nepal, Kathmandu

GoN/MoFSC/DoF (2014) Hamro Ban (Our forests). Department of Forest, Ministry of Forest and Soil Conservation, Government of Nepal, Kathmandu (in Nepali)

HNCC (2006) Prioritized medicinal plants for economic growth in Nepal. Herbs and NTFPs Co-ordination Committee, Department of Plant Resources, Ministry of Forest and Soil Conservation, Government of Nepal, Kathmandu

Humagain K, Shrestha KK (2010) Medicinal plants in Rasuwa district, central Nepal: trade and livelihood. Bot Orient J Plant Sci 6:39-46. doi:10.3126/botor.v6i0.2909

Kumar B (2009) Lichen-moss harvesting practices and their marketing strategy in Uttarakhand, India. New York Sci J 2:24-30. doi:10.7537/marsnys020409.04

Llano GA (1944) Lichens, their biological and economic significance. Bot Rev 10:1-65. doi:10.1007/ BF02861799

Maraseni TN, Shivakoti GP (2003) Policy needs in harvesting and marketing of non-timber forest products in Nepal. In: Hiremath AJ, Gladwi C, Uma Shankar R (eds) Proceedings of the South Asian Regional workshop on Policies, Utilization and Conservation of Non Timber Forest Products in South Asia Region, 28-30 April 2003, Bangalore, India. pp 241-252

Maraseni TN, Shivakoti GP, Cockfield G, Apan A (2006) Nepalese non-timber forest products: an analysis of the equitability of profit distribution across a supply chain to India. Small-scale For Econ Manag Policy 5:191-206. doi:10.1007/s11842-006-0010-8

Molleman L, Boeve S, Wolf J et al (2011) Commercial harvesting and regeneration of epiphytic macrolichen communities in the Western Ghats, India. Environ Conserv 38:334-341. doi:10.1017/ S0376892911000142

NTNC (2005) Annual report. National Trust for Nature Conservation, Lalitpur

Olsen CS (1998) The trade in medicinal and aromatic plants from Central Nepal to Northern India. Econ Bot 52:279-292. doi:10.1007/BF02862147

Olsen CS (2005) Quantification of the trade in medicinal and aromatic plants in and from Nepal. In: Franz C, Mathe A, Craker LE, Gardner Z (eds) WOCMAP III. Vol. 4: Targeted screening of MAPs, economics \& law. ISHS, Oakland, pp 29-35

Olsen CS, Larsen HO (2003) Alpine medicinal plant trade and Himalayan mountain livelihood strategies. Geogr J 169:243-254. doi:10.1111/1475-4959.00088

Pant GC (2014) Production, assessment and marketing of lichens for economic upliftment and livelihood generation of rural communities in Kumaun. J For Environ Sci 30:267-276. doi:10.7747/JFS.2014.30. 3.267

Richardson DHS (1991) Lichens and man. In: Hawksworth DHS (ed) Frontiers in mycology. 4th International Mycological Congress, Regensburg, Germany, 1990. C.A.B. International, Wallingford, pp $187-210$

Rose F (1992) Temperate forest management: its effects on bryophyte and lichen floras and habitats. In: Bates JW, Farmer A (eds) Bryophytes and lichens in a changing environment. Clarendon Press, Oxford, pp 211-233 
Scheidegger C, Goward T (2002) Monitoring lichens for conservation: Red lists and conservation action plans. In: Nimis PL, Scheidegger C, Wolseley PA (eds) Monitoring with lichens-monitoring lichens. Kluwer Academic Publishers, Printed in the Netherlands, pp 163-181

Scheidegger C, Werth S (2009) Conservation strategies for lichens: insights from population biology. Fungal Biol Rev 23:55-66. doi:10.1016/j.fbr.2009.10.003

Shah NC (2014) Lichens of commercial importance in India. Scitech J 01:32-36

Singh KP, Sinha GP (2010) Indian lichens: an annotated checklist. Botanical Survey of India, Ministry of Environment and Forests, Kolkata

Søchting U (2015) Lichens. In: Mihe G, Pendry CA, Chaudhary R (eds) Nepal: An introduction to the natural history, ecology and human environment of the Himalayas. Royal Botanic Garden Edinburgh, Edinburgh, pp 191-199

Subedi A, Kunwar B, Choi Y et al (2013) Collection and trade of wild-harvested orchids in Nepal. J Ethnobiol Ethnomed 9:64. doi:10.1186/1746-4269-9-64

Upreti DK, Divakar PK, Nayaka S (2005) Commercial and ethnic use of lichens in India. Econ Bot 59:269-273. doi:10.1663/0013-0001(2005)059[0269:CAEUOL]2.0.CO;2

Zedda L, Rambold G (2015) The diversity of lichenised fungi: Ecosystem functions and ecosystem services. In: Upreti DK (ed) Recent advances in lichenology: modern methods and approaches in lichen Systematics and culture techniques. Springer, New York, pp 121-145 